\title{
Characteristics of Entrepreneurs and the Practice of Islamic Values in Influencing the Success of Small Medium Enterprises in Kelantan and Selangor
}

\author{
${ }^{*}$ Maisarah Ahmad, Suhaila Abdul Kadir \\ National University of Malaysia UKM Bangi Selangor Malaysia \\ *sara@ukm.my
}

\begin{abstract}
Although many studies have been done in connection to the entrepreneurial characteristics, they only described the profile of entrepreneurship through the listing of characteristics and factors affecting the success of entrepreneurs. However, in this study, the researchers aim to identify the positive features and their relationship with the success of entrepreneurs in Kelantan and Selangor in terms of Islamic values practice.The study was conducted on 200 respondents in Kelantan and Selangor. Through correlation analysis, the characteristics were observed to have significant relationship with the success of small entrepreneurs. All key variables have significant relationship with the entrepreneurs' success excluding the type of product and education. The multiple regression analysis showed that the characteristics of small entrepreneurs have a positive influence on success. The results also showed that the interaction of characteristics of entrepreneurs with the Islamic values have positive correlation with success.
\end{abstract}

Keywords: Characteristics, Successful, Small Entrepreneur, Islamic Value

\section{Introduction}

Researchers associated with the characteristics of entrepreneurs in Small and Medium Enterprises (SMEs) have carried out many empirical studies. Among them are from Kirby (1992), Dollinger (1995), Zimmerer (1996), Zafir \& Fazilah (2003) and Rosli et al., (2007). However, almost all researchers only explored the characteristics of successful entrepreneurs in terms of entrepreneurial profile. Among the few researchers who tried to discuss the profile of entrepreneurship through the listing of entrepreneurial characteristics were Kao and Liang (2001) which have listed 18 characteristics of entrepreneurs; while Zaidatol and Habibah (1997) listed six characteristics of entrepreneurs. In addition, several other researchers such as Kirby (1992), Dollinger (1995), Zafir and Fazilah (2003) and McGrath et al., (1992) attempted to discuss the entrepreneurship profile through entrepreneurial characteristics. However, most of the features listed were almost similar to each other. After making further analysis, Zaidatol and Habibah (1997), has listed ten characteristics of entrepreneurs. This present study used an instrument modified from Zaidatol and Habibah (1997), after taking all views of the previous researches on the characteristics of entrepreneurs. In another study conducted by Kao (1991), there were 11 major features that an entrepreneur should have such as commitment, determination and perseverance, motivation to succeed and thrive, orientation to the opportunities and goals, take initiative and personal responsibility, continuous solution to problem, realistic, seek and use feedback, internal locus of control, taking risk, less drive towards power and status and reliability of integrity.

These are in line with the results of a study conducted by Kirby (1992), who found that the four basic features every entrepreneur should have are ability to identify role, competence, motivation and willingness to change. Until now, economists and psychologists in understanding the characteristics of an entrepreneur have conducted many studies. However, due to rapid development of SMEs across the country, many researchers are interested in doing research related to the performance of SMEs. According to, among success factors of SME that have been studied previously, including the characteristics of the manager/owner, types of entrepreneurial, or types of management manager/owner, business age, and business size based on number of employees, location and differences of industry sector. In a study conducted by Rosman (2009), it was found that the characteristic factors of owner / managers, management practices, experience, government policies, age, size, type of industry, education level and microcredit programs are among the performance factors for small enterprises. Generally, the purpose of this study is to seek the interaction between the characteristics of entrepreneurs and Islamic values in influencing the success of SMEs. The article is organized as follows: Section II discusses literature reviews, Section III describes research methodology, Section IV addresses 
statistical results, Section V highlights the discussion, and Section VI provides conclusion and recommendations of the study.

\section{Literature Review}

Some of previous researchers found that the characteristics of entrepreneurs affect business success (Nor Hasni, 2005; Ku Azilah, 2004; Zaidatol and Habibah, 1997; and Rosman, 2009). Entrepreneur's characteristics have been observed directly with success. However, a few studies have attempted to link the practice of Islamic values with the characteristics of entrepreneurs in influencing the success. Therefore, researchers have attempted to link the role of the practice of Islam with the entrepreneurs' characteristics as it has not yet been studied by previous researchers.

Entrepreneurs from a Modern Perspective: Business philosophy in the western perspective never relates the business with divinity and religious beliefs. It does not need any harshness dimension. It is not concerned with prayer and worship. It only focuses the relationship between seller and buyer and given plenty of time to satisfy the requirements of customer. Generally, the purpose of business from western perspective is to gain profit. However, business goals have been through the paradigm shift not only for profit but also to fulfil social responsibility. Among the characteristics of entrepreneurs are innovative and creative, hard-working, self-confident, determination in problem solving, possess courage to face failure and responsible (Zaidatol, 2007). These features are in line with the opinion of Noraishah (2002) which said that a successful entrepreneur is someone who is innovative because he often introduces new ideas or new methods of production. He is always trying to improve items or existing services or create new items and services to attract customers. Apart from these characteristics, another study done by Sexton and Bowman (1990) reported that successful entrepreneurs are the ones that have high energy and endurance. They are also capable of dominating the subordinates as a powerful weapon in controlling climate change and bring new ideas. An entrepreneur should also be able to survive long in solving business problems (Bacas \& Croft, 1986). The results of a study performed by Vaught and Hoy (1981) found that these values are well appreciated by entrepreneurs compared to non-entrepreneurs. The personal values are the main catalyst for entrepreneurial success. Positive values available to entrepreneurs like freedom, positive thinking, work in small, highly motivated, ambitious, confident, tolerant with difficulty and are willing to sacrifice are the factors leading to dynamic entrepreneurs (Vaught and Hoy, 1981).

Entrepreneurs from the Islamic Perspective: There are a lot of good values to be adopted by the entrepreneurs. These values and behaviors that cause them to successfully overcome many obstacles in the business. According to Mohd Nazmi (2005), among the main factors causing entrepreneurs to succeed and gain a lot of profit in the business is because they work hard and execute business according to Islamic ethics. Hardworking entrepreneur will achieve success and profit in business and pleased by Allah S.W.T. Business should be done with full dedication without feeling frustrated, demoralized or despair (Mohd Nizho \& Mohd Shukri, 2005). For example, the practice of Japanese businesspersons that are efficient enough (Maamor, 2001). Additionally, the entrepreneurs should always put the customer with utter words appealing, sweet, mutual respect, and gentleness and consider the interests of all parties. Entrepreneurs should always open-minded and strive to meet the "consumer expectation". Customer satisfaction is their priority. In Islam, the nature is a positive or admirable trait (Mahmudah). According to Shuhairimi \& Ku Halim (2010), Islam calls on its followers especially to entrepreneurs to give priority to the value of creativity and innovation in business framework. In fact, Allah S.W.T. has awarded a variety of resources for human survival. However, on a more general scale it cannot accommodate the needs of a man perfectly if the result is not optimal manipulated. Thus, entrepreneurs need to apply the value of creativity and innovation available to them to help solve some of the requirements needed by the community. Islam even recognizes that innovative and creative act is the inherent quality of the entrepreneur. This claim can be seen from Allah says, which means:

"He it is Who made the earth smooth for you, therefore go about in the spacious sides thereof, and eat of His sustenance, and to Him is the return after death".

Surah Al-Mulk (67): 15

Creative and innovative values are the important values for every entrepreneur because they are the key to success in business. This innovative nature is encouraged by Islam as Allah SWT created all things is to be used by humans. This is expressed through the verse that says: 
In addition, successful entrepreneurs also should have self-confident. This value becomes a platform for entrepreneurs to do whatever activities and resolve them wisely. In essence, Islam directs its followers to carry out a task with confidence, courage, and with diligence. As successful entrepreneurs, they have high courage and confidence to move forward in the business. This has been reiterated by Allah SWT through His word, which means:

"And be not infirm, and be not grieving, and you shall have the upper hand if you are believers" Surah al-Imran (3): 139

Clearly, it shows to us that Allah SWT forbid negative act such as grieve. It can be concluded that successful entrepreneurs do not let themselves from having negative values of a barrier and block the progress of dressing for success (Shuhairimi \& Ku Halim, 2010). That is why entrepreneurs should move boldly to take risks and seek opportunities in this field of business and entrepreneurship. According to Ivan (1999), the confidence within the entrepreneurs will produce a positive value in them in order to self-respect and believe that they are also important. It is essential because people not only manage a physical aspect, but also the emotional and mental health. It turns out that self-confidence is part of the fundamental values available in successful entrepreneurs to act more mature. The higher the entrepreneur's ability to build his self-confidence, the greater the confidence and their willingness to try something that is seen by others as a risk. Those who have high self-confidence have the ability to take the right decision. This can be helpful to the success of their business (Meredith in Shuhairimi \&Ku Halim, 2010).

Entrepreneurs from a modern perspective measure external success in terms of profits obtained in the world, but entrepreneurs from the Islamic perspective not only measure success in terms of profitability in the world but emphasizing the consideration obtained in the afterlife. This difference can be seen in the modern and Islamic perspective of business. There are many factors that can influence the success of an entrepreneur. According to Rosli et al., (2007), among the general characteristics often associated with the personality of an entrepreneur are the drive, take calculated risks, diligence, commitment, determination and perseverance, initiative and responsibility, internal locus of control, confidence in their abilities, honesty and keeping promises, emphasizing the high quality of work, ability to solve problems, high levels of labour force, oriented goals and vision, the ability to make decisions, use of influence strategies and social entrepreneurship. According to Litzinger (1965), among the values that an entrepreneur should adopt are taking big risk, independence, leadership, generosity, optimism, power, care, high need for achievement and confidence. These features are also encouraged in Islam. In fact, according to Abdul Mumin and Suhaili (2005), the Prophet Muhammad S.A.W himself was an entrepreneur who practiced good qualities, and his business was more profitable than the dishonest entrepreneur was. Characteristics, behaviors and attitudes can be categorized as a positive attitude or praiseworthy (Mahmudah). According to Mohd Nazmi et al., (2005), among the main factors causing the entrepreneurs to get a lot of success and profit in business are hardworking and do business according to ethical standards outlined by Islam. As an individual who is always looking out for opportunities, the values of creative and innovative are very important for each individual entrepreneur. The nature of innovative is encouraged by Islam since God created everything to be used by human. This is revealed through the Word of God, which reads:

"He (Allah) Who created for you whatsoever is in the earth" (Surah al-Baqarah: Verse 29)

The verse explains that God created all things in the face of this earth for the benefit of humankind. However, people need to think how to change the basic resources to products that meet their needs. Therefore, they are blessed with common sense and this privilege should be used preferably for the benefit of all parties. Creativity is reflected through a piece of Hadith:

"Talhah bin 'Ubaidullah told: "I was walking with the Prophet through the garden of palms and the Prophet had seen a race that pollinates the trees. Then, the Prophet asked what are they doing? They said that they took the male flowers and unite them with female seeds. The Prophet felt that it would not work thus, the people left the activity. The news came to the Prophet and the Prophet said that it was only a thought, but if you think it works, then go ahead, as indeed I am a human like you and my thought is sometimes right and sometimes wrong, but if I say God said it is, then I never lie about it". (Sunan Ibn Majah, Kitab al-ahkam, Bab Talkih al-Nahl, no. 2461) 
This Hadith showed that the Prophet did not prevent his followers to carry out new and improved methods of old methods in order to increase the yields. In today's world, a variety of modern technologies and processes has been introduced to produce a better product, which is easily marketed. It should be the focus of Muslim entrepreneurs to not only learn, but also create new and better technology (Abd Mumin \& Suhaili, 2005). Therefore, this study was carried out in order to determine whether the success of entrepreneurs is influenced by their positive characteristics and their relationship to the practice of Islamic values.

\section{Methodology}

Variables and Measures: Characteristics of small entrepreneurs in Peninsular Malaysia are the focus of the present study. Characteristics of small entrepreneurs (27 items) were adapted from a study conducted by Zaidatol and Habibah (2004). The research design employed in this study was descriptive research survey using questionnaire. The questionnaires were answered by small entrepreneurs in Kelantan and Selangor. Using five-point Likert scale, ranging from 1 (strongly disagree) to 5 (strongly agree), the respondents were required to indicate the degree of agreement over 27 items encompassing characteristics of small entrepreneurs in order to run their businesses. Small industries were mostly owned and managed by the same person. These entrepreneurs were involved in all levels of daily management and operations. As such, it was believed that they know best how to rate their own characteristics.

Survey Instrument and Sample: Data were collected from the sample respondents using a selfadministered questionnaire. Questions on soliciting characteristics were asked as well as questions on entrepreneur and business profiles. To ensure validity and reliability of the questionnaire, a pilot study was carried out in January 2010 on 40 respondents in Kelantan (less developed region) and in Selangor (more developed region). Mean of Cronbach Alpha score for characteristics is 0.92 . The pilot survey was found to be a good exercise for the study due to the fact that a number of questions were not respondentfriendly, which were then refined for better digestion. From the 2000 population in the sample frame provided by a government agency responsible in managing small entrepreneurs, 250 respondents were selected for the actual study. A survey was performed from March to June 2010. The collection of data in this study was rather time-consuming as the respondents were located in different regions. In each region, the respondents were spread out in many geographical areas in which the distance from one place to another was quite far. Several respondents could not be located due to the business relocation and closure or inaccurate addresses provided. Finally, 200 questionnaires were completed and analyzed in this study.

\section{Results}

A. Correlation Analysis: From Table 1, it can be seen that there was significant correlation between the positive features of entrepreneurs such as attitudes, skills and self-efficacy on the success of their businesses. It is found that the relationship between Islamic values and characteristic of entrepreneur such as behaviours, skills and self-efficacy were positively related with the value of $p<0.01$. The results are shown in Table 2.

Table 1: Relationship between Two Variables

\begin{tabular}{|c|c|c|c|c|c|c|c|c|c|c|c|c|}
\hline & Variables & Mean & SD & 1 & 2 & 3 & 4 & 5 & 6 & 7 & 8 & 9 \\
\hline 1 & $\begin{array}{l}\text { Type of } \\
\text { product }\end{array}$ & 14.73 & 7.96 & 1 & & & & & & & & \\
\hline 2 & $\begin{array}{ll}\text { Age } & \text { of } \\
\text { business }\end{array}$ & 3.56 & 1.33 & $0.157^{*}$ & 1 & & & & & & & \\
\hline 3 & Business size & 1.71 & 0.081 & $-0.171^{*}$ & $-\overline{0.357^{* *}}$ & 1 & & & & & & \\
\hline 4 & Education & 5.14 & 1.90 & 0.082 & 0.041 & -0.003 & 1 & & & & & \\
\hline 5 & $\begin{array}{l}\text { Characteristic } \\
\text { of } \\
\text { entrepreneurs }\end{array}$ & 4.46 & 0.34 & 0.091 & -0.019 & -0.076 & $\begin{array}{l}- \\
0.074\end{array}$ & 1 & & & & \\
\hline 6 & Behaviour & 4.43 & 0.49 & $0.147^{*}$ & -0.114 & -0.035 & 0.071 & $0.622^{* *}$ & 1 & & & \\
\hline 7 & Skills & 4.47 & 0.44 & 0.085 & 0.068 & $-0.172^{*}$ & 0.045 & $0.805^{* *}$ & $0.666^{* *}$ & 1 & & \\
\hline 8 & Self-efficacy & 4.47 & 0.52 & 0.082 & 0.089 & $-\overline{0.201^{* *}}$ & 0.089 & $0.694^{* *}$ & $0.610^{* *}$ & $0.887^{* *}$ & 1 & \\
\hline 9 & Islamic values & 2.84 & 0.26 & 0.082 & 0.079 & -0.048 & 0.136 & $0.430^{* *}$ & $0.293^{* *}$ & $0.383^{* *}$ & $0.306^{* *}$ & 1 \\
\hline 10 & Success & 3.56 & 0.51 & -0.004 & $-0.167^{*}$ & $0.454^{* *}$ & 0.104 & $0.373^{* *}$ & $0.377^{* *}$ & $0.412^{* *}$ & $0.366^{* *}$ & $0.299^{* *}$ \\
\hline
\end{tabular}


B. Multiple Regression Analysis: Table 2 shows that the size of industries has a positive influence on the success of the first model. However, the second model showed that size of industries, skills and selfefficacy indicated a positive influence on success. These findings were consistent with the results of Zaidatol and Habibah (2004). In the third model, the size of industries, skills and self-efficacy also have positive influence on success. This finding was consistent with the results reported by Khalid (1968). The fourth model showed that the size of industries, skills, self-efficacy, interaction effects between Islamic values and characteristics of entrepreneur, Islamic values and skills and Islamic values and self-efficacy also positively influenced the success. The coefficient of determination, $\mathrm{R}^{2}$ of the fourth model recorded 0.745 . This showed that $74.5 \%$ of dependent variables namely the success of SME can be explained by the independent variables such as age of business, saiz of business, skills, self-efficacy and interaction between characteristics of entrepreneurs, skills and self-efficacy with Islamic values. While, the adjusted $R^{2}$ was 0.727. The study also supported the views of Abd Mumin \& Suhaili (2005), and Dahlan \& Humam, (2000) which stated that the Prophet himself was an entrepreneurs who practiced good qualities, but his business is still profitable than the dishonest entrepreneurs. Entrepreneurs should be ready and must have courage to face any eventuality in the execution of business such as risk as this will determine the rate of profit to be derived (Khalid, 1968).

Table 2: Multiple Regression Analysis

\begin{tabular}{|c|c|c|c|c|}
\hline & Model 1 & Model 2 & Model 3 & Model 4 \\
\hline \multicolumn{5}{|l|}{ Step 1: Control } \\
\hline Type of product & $\begin{array}{l}-0.002 \\
(-0.130)\end{array}$ & $\begin{array}{l}-0.008 \\
(-0.899)\end{array}$ & $\begin{array}{l}-0.008 \\
(-0.902)\end{array}$ & $\begin{array}{l}-0.004 \\
(-0.485)\end{array}$ \\
\hline Age of business & $\begin{array}{l}-0.032 \\
(-1.291)\end{array}$ & $\begin{array}{l}-0.039 \\
(-2.693)^{* *}\end{array}$ & $\begin{array}{l}-0.039 \\
(-2.700)^{* *}\end{array}$ & $\begin{array}{l}-0.033 \\
(-2.203)^{*}\end{array}$ \\
\hline Business Size & $\begin{array}{l}0.185 \\
(4.443)^{* * *}\end{array}$ & $\begin{array}{l}0.269 \\
(11.079)^{* * *}\end{array}$ & $\begin{array}{l}0.269 \\
(11.047)^{* * *}\end{array}$ & $\begin{array}{l}0.269 \\
(11.186)^{* * *}\end{array}$ \\
\hline Education & $\begin{array}{l}0.021 \\
(1.264)\end{array}$ & $\begin{array}{l}0.010 \\
(1.070)\end{array}$ & $\begin{array}{l}0.010 \\
(1.000)\end{array}$ & $\begin{array}{l}0.012 \\
(1.272)\end{array}$ \\
\hline \multicolumn{5}{|l|}{ Step 2: Main effect } \\
\hline Characteristics of entrepreneur & & $\begin{array}{l}0.016 \\
(0.063)\end{array}$ & $\begin{array}{l}0.001 \\
(-0.004)\end{array}$ & $\begin{array}{l}0.026 \\
(0.097)\end{array}$ \\
\hline Behaviour & & $\begin{array}{l}-0.099 \\
(-1.662)\end{array}$ & $\begin{array}{l}-0.098 \\
(-1.633)\end{array}$ & $\begin{array}{l}-0.115 \\
(-1.936)\end{array}$ \\
\hline Skill & & $\begin{array}{l}0.557 \\
(2.986)^{* *}\end{array}$ & $\begin{array}{l}0.561 \\
(2.991)^{* *}\end{array}$ & $\begin{array}{l}0.583 \\
(3.142)^{* *}\end{array}$ \\
\hline Self-efficacy & & $\begin{array}{l}0.301 \\
(3.307)^{* *}\end{array}$ & $\begin{array}{l}0.306 \\
(3.279)^{* *}\end{array}$ & $\begin{array}{l}0.313 \\
(3.432)^{* *}\end{array}$ \\
\hline \multicolumn{5}{|l|}{ Step 3: Moderators } \\
\hline Islamic values & & & $\begin{array}{l}0.014 \\
(0.273)\end{array}$ & $\begin{array}{l}0.021 \\
(0.395)\end{array}$ \\
\hline \multicolumn{5}{|l|}{ Step 4: Interaction effects } \\
\hline $\begin{array}{l}\text { Islamic values x Characteristics of } \\
\text { entrepreneur }\end{array}$ & & & & $\begin{array}{l}2.021 \\
(2.958)^{* *}\end{array}$ \\
\hline Islamic values x Behaviour & & & & $\begin{array}{l}-0.053 \\
(-0.213)\end{array}$ \\
\hline Islamic values x Skill & & & & $\begin{array}{l}1.188 \\
(2.897)^{* *}\end{array}$ \\
\hline Islamic values x Self-efficacy & & & & $\begin{array}{l}0.562 \\
(2.242)^{*}\end{array}$ \\
\hline Constant & 3.616 & 0.108 & 0.085 & 0.057 \\
\hline$R^{2}$ & 0.139 & 0.726 & 0.726 & 0.745 \\
\hline Adjusted $R^{2}$ & 0.121 & 0.714 & 0.713 & 0.727 \\
\hline Statistical $F$ & $7.843^{* * *}$ & $63.215^{* * *}$ & $55.928^{* * *}$ & $41.766^{* * *}$ \\
\hline
\end{tabular}

Discussion: Entrepreneurs should work diligently or do business in order to achieve success and profitability which please Allah S.W.T. The business needs to be done with full dedication without frustration, weak-willed or despair (Mohd Nizho, 2005). The practice of high competency like Japanese entrepreneurs is an example (Maamor, 2001). The positive values in entrepreneur are factors that lead to a dynamic entrepreneur. In fact, in business, Islam does not ignore the positive values such as peace, security, honesty and tolerance in which the unity among these values which conform to Islamic teachings and principles of entrepreneurship is perceived as symbiosis. In Islam, the entrepreneurs are 
also encouraged to be diligent, creative, dare to take risk and highly motivated. These values are necessary for every entrepreneur to be more successful in the underlying business (Shuhairimi \& $\mathrm{Ku}$ Halim, 2010). These findings also supported the ideas presented by Eman (2008), which stated that creativity and innovation are the positive features that should be owned by the successful individual entrepreneurs. Positive characteristics such as creative can distinguish between entrepreneurs and others. While, innovation is the ability of entrepreneurs to apply the creative ideas on problems and opportunities in order to improve the productivity and performance (Zimmerer et al., 2008).

\section{Conclusion and Recommendations}

Findings also showed that the variable of entrepreneurial characteristics has positive relationship with the practice of Islamic values and success. This means that these variables were connected to each other and achieved high level of significance. Among the major factors leading, the entrepreneurs to success and profit in business are due to hard work and execution of business according to Islamic ethics (Mohd Nazmi, 2005). It is clear that the success of SMEs depends on the characteristics of entrepreneurs and the practice of Islamic values practiced by those entrepreneurs. Hopefully in the future, more SME-related researches associate with the practice of moral values in achieving success will be carried out and viewed from a wider angle in term of influence of demographic and assistance from the government.

\section{References}

Al-Quran.

Al-Hadith.

Mumin, A. B., Ghani, A. B. \& Suhaili, S. (2005). Penerapan budaya keusahawanan dalam masyarakat Islam. Seminar Keusahawanan Islam Peringkat Kebangsaan. Akademi Pengajian Islam, Universiti Malaya, Kuala Lumpur.

Bacas, H. \& Croft, J. L. (1986). Go Out On Your Own? Nation's Business, March.

Dahlan, I. \& Humam, M. (2000). Keusahwanan Islam. Kuala Lumpur: Pearson-Prentice Hall.

Dollinger, M. (1995). Entrepreneurship: Strategies and resources. In Alfred Marshall, The Principle of Economics. (1946). Illinois: Irwin.

Eman, S. (2008). Business Entrepreneur. Bandung: Alfabeta.

Ivan, B. (1999). The power of positive doing: 12 strategies for control your life. Dlm. Dlm. Shuhairimi Abdullah \& Ku Halim Ku Ariffin. Membentuk peribadi usahawan berjaya (pp. 61-75). Kangar: Universiti Malaysia Perlis.

Kao, J. J. (1991). The entrepreneur. Englewood Clis: Prentice Hall.

Kao, R. W. \& Liang, T. W. (2001). Entrepreneurship and Enterprise Development in Asia. New York: Prentice Hall.

Khalid, M. K. (1968). Rijal Haula al-Rasul. Kaherah: dar al Kitab al- Hadithah, pp. 642.

Kirby, D. (1992). Developing graduate entrepreneurs: The U.K. graduate enterprise programme. Entrepreneurship, innovation and change, 1(2).

Ku-Azilah, K. M. (2004). Pendidikan strategi keusahawanan: Pelajaran dari ejen insuran hayat yang berjaya dalam industri insurans Malaysia. Tesis Ph.D. Universiti Kebangsaan Malaysia, Bangi.

Litzinger, W. D. (1965). The Model Entrepreneur and the Motel Manager. Academy of Management Journal, $8,268-281$.

Ma'amor, O. (2001). Nilai-Nilai Universal Etika Perniagaan Islam, dlm. Dunia Islam, Bil. 73, Oktober 2001. Kuala Lumpur: Current Fleet Publishing (M) Sdn. Bhd, hlm. 54-56.

McGrath, R. G., MacMillan, I. C. \& Scheinberg, S. (1992). Elitists, risk takers, and rugged individualists? An exploratory analysis of culture differences between entrepreneurs and non-entrepreneurs. Journal of Business Venturing, 7(2), 115-135.

Meredith, G. G., Nelson, R. E. \& Neck, P. A. (1982). The practice of Entrepreneurship. Dlm. Shuhairimi Abdullah \& Ku Halim Ku Ariffin. Membentuk peribadi usahawan berjaya (pp. 38-39). Kangar: Universiti Malaysia Perlis.

Mohd-Nazmi, D., Mohd-Suki, O. \& Rijaluddin, Y. (2005). Pendidikan Islam Tingkatan Dua. Kuala Lumpur: Kementerian Pendidikan Malaysia \& Dewan Bahasa dan Pustaka.

Mohd-Nizho, A. R. \& Mohd-Shukri, H. (2005). Etika perniagaan dari perspektif Al-Quran: satu tinjauan. Seminar keusahawanan Islam II Peringkat Kebangsaan. Akademi Pengajian Islam, Universiti Malaya, Kuala Lumpur.

Nor-Aishah, B. (2002). Asas keusahawanan. Kuala Lumpur: Penerbit Fajar Bakti Sdn. Bhd. 
Nor-Hasni, O. (2005). Keefisienan dan amalan perniagaan usahawan kecil bumiputera di Negeri Kedah Darul Aman. Tesis Doktor Falsafah. Bangi: Universiti Kebangsaan Malaysia.

Rosli, M., Lily-Julienti, A. B., Mohamad-Yusof, M. J., Muhammad-Shukri, B., Norita, D., Norria, Z., Syahrina, A., Rosli, M. S. \& Azrain, N. M. (2007). Prinsip-Prinsip Asas Keusahawanan.Thomson Learning Publication: Universiti Utara Malaysia.

Rosman, M. (2009). Prestasi Perusahaan Kecil: Satu kajian perbandingan ke atas program mikrokredit Amanah Ikhtiar Malaysia (AIM) dan Tabung Ekonomi Kumpulan Usaha Niaga (TEKUN). Tesis Ph.D. Universiti Malaya.

Sexton, D. L. \& Bowman, N. (1990). The Entrepreneur: A Capable executive \& more. Journal of Business Venturing, 1(2).

Shuhairimi, A. \& Ku-Halim, K. A. (2010). Membentuk peribadi usahawan berjaya. Kangar: Universiti Malaysia Perlis.

Vaught, B. C. \& Hoy, F. (1981). Have You Got What It Take to Run Your Own Business? Business. July August.

Zafir, M. \& Fazilah, M. H. (2003). Menjadi usahawan. Bentong. PTS Publications \& Distributors Sdn. Bhd.

Zaidatol, A. L. P. \& Habibah, E. (1997). Keusahawanandan motivasi diri. Serdang: Universiti Putra Malaysia Press.

Zaidatol, A. L. P. \& Habibah, E. (2004). Keupayaan usahawan Bumiputera melaksanakan kemahiran keusahawanan: Satu kajian kes. Pertanika Journal Social Science \& Humanities, 12, 61-70.

Zaidatol, A. L. P. (2007). Usahawan dan keusahawanan satu perspektif pendidikan. Serdang: Universiti Putra Malaysia.

Zimmerer, W. T. \& Scarborough, N. M. (1996). Entrepreneurship and new venture formation. New Jersey: Prentice hall.

Zimmerer, W. T., Scarborough, N. M. \& Wilson, D. (2008). Essential of entrepreneurship and small management. Upper Saddle River N.J: Prentice Hall. 